\title{
Transformasi Hukum Islam pada Masyarakat di Indonesia
}

\author{
Hesti Nur Hidayah ${ }^{1}$ dan Ashif Az Zafi ${ }^{2}$ \\ ${ }^{1,2}$ Fakultas Tarbiyah, IAIN Kudus \\ Corresponding author. Email: hesti11puji@gmail.com
}

Naskah diterima: 14-04-2020; revisi: 13-10-2020; disetujui: 17-12-2020

DOI: https://doi.org/10.46257/jrh.v24i2.118

\begin{abstract}
Abstrak
Hukum Islam termasuk ke dalam hukum perundang-undangan di Indonesia melalui proses penyatuan hukum. Hukum Islam di Indonesia diadakan pembaharuan yang disesuaikan dengan keadaan masyarakat dan perkembangan zaman. Dalam prosesnya, hukum Islam diunifikasikan dengan hukum adat dan hukum barat. Dengan tujuan agar hukum di Indonesia sesuai dengan nilai-nilai luhur masyarakat yang sehingga bisa dilaksanakan masyarakat Indonesia dengan baik. Rumusan masalah bagaimana proses transformasi hukum Islam di Indonesia dan pengaruhnya terhadap masyarakat di Indonesia, kedua apa itu kompilasi hukum islam dan bagaimana perananya dalam masyarakat Indonesia. Tujuan penelitian untuk menjelaskan proses transformasi dan peranan hukum Islam di negara Indonesia. Kegunaan penelitian untuk menambah pengetahuan mengenai sejarah dan perkembangan hukum di Indonesia. Metode Penelitian ini yaitu penelitian kepustakaan. Hasil penelitian ini meliputi sejarah adanya transformasi hukum Islam di Indonesia dalam bidang pidana maupun dalam bidang perdata serta pengaruhnya dalam masyarakat, dan Kompilasi Hukum Islam. Kesimpulan dari penelitian ini yaitu hukum Islam hadir di Indonesia dan menjadi hukum positif di Indonesia. Serta hukum positif ini bertujuan menyelesaikan permasalahan yang ada di masyarakat.
\end{abstract}

Kata kunci: hukum Islam, transformasi hukum Islam, Kompilasi Hukum Islam (KHI).

\section{Transformation of Islamic Law on Indonesian Society}

\begin{abstract}
Islamic law is included in statutory law in Indonesia through a process of legal unification. Islamic law in Indonesia is subject to reforms that are adjusted to the conditions of society and the times. The formulation of the problem of how the process of transforming Islamic law in Indonesia and its impact on society in Indonesia, both what is the compilation of Islamic law and how it plays a role in Indonesian society. In the process, Islamic law was unified with customary law and western law. With the aim that the law in Indonesia is in accordance with the noble values of society so that the Indonesian people can implement it properly. The research objective is to explain the transformation process and the role of Islamic law in the Indonesian state. Usefulness of research to increase knowledge about the history and development of law in Indonesia. This research method is library research. The result of this study includethe history of the existence of the transformation of Islamic law in
\end{abstract}


Indonesia in the criminal sector as well as in the civil sector and its influence on society, and the Compilation of Islamic Law. The conclusion of this research is that Islamic law is present in Indonesia and becomes positive law in Indonesia. As well as this positive law aims to solve problems that exist in society.

Keywords: Islamic law, transformation of Islamic law, Compilation of Islamic Law (KHI).

\section{Pendahuluan}

Hukum Islam mempunyai nilai lebih yang tidak bisa didapatkan oleh hukum yang dibuat manusia. Hukum Islam memiliki balasan dunia dan akhirat. Hukum Islam ada karena untuk melengkapi kebutuhan manusia serta untuk mengatur manusia dalam menjalani kehidupan sehari-hari. Pelaksanaanya sesuai dengan iman yang dimiliki oleh setiap individu. Hukum Islam hadir mampu menyelesaikan permasalahan yang ada di masyarakat. Selain bersumber dari Alqur'an dan Hadits, Hukum Islam yang ada di Indonesia juga berasal dari hasil ijtihad dan hukum yang dikeluarkan oleh negara yang tujuanya untuk mencapai kebaikan secara menyeluruh. Masyarakat harus mengikuti peraturan yang dibuat oleh negara sesuai dengan QS al-Nisa' (4): 59:

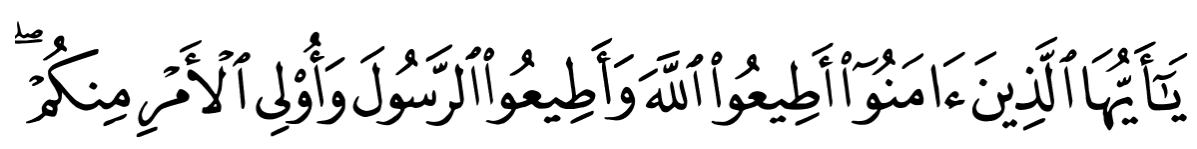

Yang artinya: Hai orang-orang yang beriman, taatlah kepada Allah, kepada rasul dan Ulil Amri (pemimpin) di kalangan kamu. (QS al-Nisa' (4): 59) (Anwar Sadat, 2018:2)

Dalam pelaksanaan kehidupan sosial, diperlukan konsep hukum yang dapat diterima masyarakat dan yang sesuai dengan sifat karakteristik dan pola kehidupan masyarakat. Hukum tidak hanya sekedar sekumpulan peraturan. (Ali Imron, 2008: 123) Artinya ada hubungan atau keterkaitan antara hukum dengan keadaan masyarakat. Karena masyarakat Indonesia memiliki perbedaan suku, agama, ras, dan golongan yang berbeda sehingga hukum di Indonesia dibuat dan disesuaikan dengan karakteristik dan nilai-nilai luhur masyarakat sehingga bisa diterima dan diterapkan oleh masyarakat. Hukum Islam menjadi bagian dari sumber hukum yang juga ditegakkan di Indonesia. Hukum Islam yang ada di 
Indonesia diadakan pembaharuan. Pembaharuan ini bertujuan supaya hukum Islam ini sesuai dengan masyarakat dan sesuai dengan keadaan zaman di Indonesia. Selanjutnya hukum Islam di unifikasikan dengan hukum adat dan hukum barat. Tujuan unifikasi hukum Islam ini agar hukum di Indonesia sesuai dengan nilai-nilai luhur masyarakat yang sehingga bisa dilaksanakan masyarakat Indonesia dengan baik. Unifikasi tiga hukum (hukum Islam, hukum adat, dan hukum barat) di Indonesia akan dibahas di dalam Kompilsi Hukum Islam.

Penelitian sebelumnya membahas tentang hukum Islam. Hukum Islamic adalah seperangkat peraturan yang dipromosikan menyesuaikan hubungan manusia dengan Allah, manusia dengan lingkungan berdasarkan doktrin Islam. Hukum Islam telah didirikan di Indonesia dan dilaksanakan secara efektif di Pengadilan Agama Indonesia berdasarkan UU Nomor 71989 tentang Peradilan Agama. Hukum mencakup bidang pernikahan, warisan, akan, hadiah, manfaat dan sedekah. Selain itu, terutama di Aceh, dengan fitur yang aneh, hukum Islam telah diterapkan secara normatively, dan di beberapa daerah telah diterapkan berdasarkan peraturan daerah. Dengan adanya hal ini, meskipun hukum formal dalam cara hukum Islam di Indonesia secara adil diterapkan dalam hukum perdata yang terbatas, namun masyarakat Muslim telah melangkah maju dalam menerapkan hukum Islam di berbagai lembaga sosial Islam. (Ahmad Yasa, 2015: 1). Sedangkan penulis membahas sejarah dan perkembangan transformasi hukum Islam di Indonesia. Selain itu juga membahas Kompilasi Hukum Islam yang mana merupakan salah satu hasil transformasi hukum islam yang sekarang menjadi hukum positif di Indonesia untuk menyelesaikan permasalahan perkawinan, pewarisan dan perwakafan di masyarakat. Relevansi dengan penelitian terdahulu adalah bahwa sama-sama membahas hukum Islam yang meliliputi hukum perkawinan, hukum perwarisan dan hukum perwakafan. Selain itu hubungan artikel penulis dengan penelitian terdahulu yaitu bahwa hukum Islam yang diterapkan di Indonesia disesuaikan dengan perundangundangan.

Penelitian sebelumnya tentang hukum keluarga Indonesia. Hukum Keluarga Indonesia yaitu penjelasan hukum keluarga dalam Islam. Masalah yang dibahas 
meliputi masalah hukum perkawinan. Hukum perkawinan dalam perkembangannya mengalami proses pembentukan yang membutuhkan waktu yang lama. Dalam sejarah pembaharuan hukum perkwinan Islam di Indonesia ada 3 periode, yaitu periode sebelum kedatangan penjajah, kolonialisme dan kemerdekaan. Periode kemerdekaan dibagi menjadi 3 periode, yaitu Orde Lama, Orde Baru dan periode reformsi. Selama Orde Lama, UU Nomor 22 tahun 1946 tentang (pencatatan nikah, talak, dan rujuk diseluruh daerah luar jawa dan madura) dan UU Nomor 32 dari 1954 berisi tentang penetapan berlakunya undang-undang republik Indonesia lahir. Dalam Orde Baru, UU Nomor 1 tahun 1974 berisi tentang perkawinan dan instruksi Presiden Nomor 1 dari 1991 berisi tentang Kompilasi Hukum Islam lahir mengenai penyusunan hukum Islam. Selama reformasi, pemerintah dan tim Pengurus utama gender merancang sebuah rancangan revisi atas kompilasi hukum Islam. (Nurhikmah Hairak Biga, 2017: 1). Sedangkan penelitian penulis membahas sejarah dan perkembangan transformasi hukum islam di Indonesia yang juga meliputi hukum perdata maupun hukum pidana. Selain itu juga membahas Kompilasi Hukum Islam yang mana Kompilasi Hukum Islam merupakan salah satu hasil transformasi hukum Islam yang sekarang menjadi hukum positif di Indonesia untuk menyelesaikan permasalahan perkawinan, pewarisan dan perwakafan di masyarakat. Relevansi penelitian terdahulu dengan penelitian ini yaitu bahwa transformasi melalui proses yang sangat panjang. Dengan adanya transformasi hukum Islam di Indonesia proses Pembaharuan hukum Islam di Indonesia pun terjadi dari masa ke masa. Proses ini mulai zaman penjajahan sampai pasca kemerdekaan. Selain itu juga yang berhubungan adalah membahas tentang Kompilasi Hukum Islam.

Penelitian terdahulu tentang eksistensi kompilasi Hukum Islam pasal 183 dalam penyelesaian masalah warisn masyarakat muslim di Makassar. sumber utama hukum Islam yaitu Al-Qur'an dan hadits Nabi. Dua sumber dapat dimengerti dan dipraktekkan berdasarkan aspek teori maupun praktikmereka, serta dikembangkan oleh ulama Mujtahid yang juga memperhatikan ruang dan waktu dan disesuaikan dengan situasi dan kondisi sehingga menghasilkan Kompilas hukum Islam. Salah satu isi dari kompilasi hukum Islam adalah aturan 
tentang pengalihan warisan properti kepada ahli waris yang masih hidup. Dengan adanya aturan ini, praktek pengalihan warisan kepada masyarakat Muslim khususnya di kota Makassar bermacam-macam. Ada dengan cara hibah, ada yang dengan cara musyawarah, ada yang dengan cara pendekatan untuk hukum warisan Islam, dan juga ada melalui mediasi yang dipimpin oleh pengadilan agama. (Andi Herawati, 2019: 1). Sedangkan penelitian penulis membahas sejarah dan perkembangan transformasi hukum islam di Indonesia. Selain itu juga membahas Kompilasi Hukum Islam yang mana Kompilasi Hukum Islam wujud dari transformasi hukum Islam yang sekarang menjadi hukum positif di Indonesia untuk menyelesaikan permasalahan perkawinan, pewarisan dan perwakafan di masyarakat. Relevansi penelitian ini dengan penelitian penelitian terdahulu yaitu peran kompilasi hukum islam dalam menyelesaikan permasalahan di masyarakat. Permasalahan-permasalahan ini tentunya berhubungan dengan pernikahan, perwarisan, dan perwakafan.

Keterangan di atas menghasilkan rumusan masalah yang mana akan dibahas pada bagian pembahasan:

a. Bagaimana transformasi hukum Islam ?

b. Bagaimana pengaruhnya dalam masyarakat serta kompilasi hukum islam dan perananya dalam masyarakat Indonesia ?

Metodologi penelitian dalam penelitian ini merupakan penelitian kepustakaan. Pengumpulan data dilakukan dengan cara menganalisis dari beberapa sumber buku dan jurnal, yang dalam hal ini bertujuan untuk lebih menjelaskan tentang koridor hukum islam, transformasi hukum islam dan pengaruhnya terhadap masyarakat Indonesia dan kompilasi hukum islam.

\section{Pembahasan}

Indonesia merupakan negara yang mana masyarakatnya banyak yang beragama Islam. Walaupun memiliki penduduk muslim terbanyak di dunia, dan walaupun ada pengakuan terhadap piagam Jakarta namun Indonesia tidak bisa dijuluki sebagai negara Islam. Arti dari Pengakuan Piagam Jakarta dalam Dekrit Presiden RI 1959 diantaranya hukum Islam hanya di berlakukan untuk pemeluk- 
pemeluknya. Sebagai upaya penerapan hukum Islam, muncul pemikiranpemikiran baru yang sesuai dengan perkembangan zaman.

Lembaga hukum Islam di Indonesia melalui banyak tantangan. Hal ini disebabkan karena kolonial Belanda kekhawatiran jika hukum Islam ditegakkan di Indonesia. Pemerintah kolonial menganggap jika ada lembaga hukum Islam akan menghalangi rencana-rencana yang telah dibuat oleh kolonialisme. Anggapan ini diwariskan kolonialisme kepada masyarakat Indonesia pasca kemerdekaan. Sehingga masyarakat menganggap hukum Islam menghalangi pembangunan. Anggapan ini merupakan skenario kolonial Belanda. Dengan demikian, masyarakat berusaha untuk menghapus ajaran-ajaran Islam agar tidak menjadi hukum yang berlaku di Indonesia. Pertentangan itu terjadi ketika UU Nomor 7 Tahun 1989 tentang Peradilan Agama disahkan dan terjadi perubahan 2 kali. Walaupun demikian, lembaga hukum tetap berusaha untuk menyempurnakan.

Pada masa penjajahan Belanda muncul ide yang cemerlang yaitu menjadikan sistem Hukm Islam sebagai Sistem Hukum Nasionl. Pemerintah Belanda menerapkan hukum Belanda di daerah yang dikuasainya. Akan tetapi tidak dapat berjalan, sehingga mereka memberikan keleluasaan lembaga masyarakat. Kewenangan bagi orang asli Indonesia menggunakan hukum Islam ini dijelaskan dalam Statuta Jakarta tahun 1624. Pemerintah VOC (Vereenigde Oost Indische Compagnie) meminta pada D.W. Freijer untuk membentuk kompendium yang berisi tentang hukum perkawinan dan hukum kewarisan Islam yang kernudian lebih dikenal dengan compedium freijer. Kebijkan Hukum Islam terus berlangsung hingga 2 abad, pemerintah Belanda menguasai Indonesia ketika masa pemerintahan VOC telah berakhir. Pada zaman ini hukum Islam diberlakukan dengan 2 kebijaksanaan yaitu teori Receptio in Complexu dan Theori Receptie .

Pada teori pertama yaitu teori Receptio in Complexu yang menjelaskan bahwa hukum Islam berlaku secara utuh pada orang Islam dan juga orang yang telah memeluk agama Islam berhak mengikuti dan menjalankan hukum agamanya. Teori ini di ketuai oleh Prof. Mr. Lodewijk Willem Christiaan Van 
den Berg (1845-1927). Teori ini berbeda dengan teori Receptie. Teori Receptie dipelopori oleh Christian Snouck Hurgronje (1857-1936). Teori ini dikembangkan oleh Cornelis van Vollenhoven (1874-1933) dan Betrand Ter Haar Bzn. (Marzuki Wahid dan Rumadi, 2001: 89-90)

Salah satu perkembangan dari teori Receptie yaitu teori Receptio a Contrario yang merupakan antonim dari teori Receptie. Teori ini mengokohkan keberadaan hukum Islam di Indonesia. Teori ini disebut dengan teori eksistensi. Teori- teori ini meliputi:

a. Ada, sebagai salah satu bagian dari hukum nasional Indonesia

b. Ada, karena adanya kekuatan dan wibawa yang diakui oleh hukum nasional di Indonesia

c. Ada, karena norma hukum (agama) dalam hukum islam berguna sebagai penyaring material-material dalam hukum nasional

d. Ada, karena sebagai komponen utama dalam hukum nasional di Indonesia. (Marzuki dan Rumadi, 2001: 92)

Teori-teori di atas merupakan salah satu bukti perkembangan hukum Islam di Indonesia. Seiring berkembang pesat pembangunan Indonesia tatanan kehidupan masyarakat berkembang sesuai dengan arus zaman. Selain itu juga berpengaruh pada praktik beragama yang akhirnya terjadi pembaharuanpembaharuan hukun Islam. Umat Islam di Indonesia memahami hukum Islam yang mereka menemukan dalam kitab-kitab fikih yang didapatkan dari ijtihad para mujtahid.

Kata transformasi memiliki arti mengubah bentuk dasar menjadi bentuk lain tanpa mengubah kaidah aslinya. (Departemen Pendidikan Nasional, 1209: 2005) mentransformasikan hukm Islam kedalam hukum Nasional mengandung arti konsepsi (rancangan yang masih ada di fikiran). (Departemen Pendidikan Nasional, 2005: 588) Dalam proses transformasi Hukum islam digabungkan dengan perundang- undangan. Penggabungan hukum Islam dalam undangundang di Indonesia dibedakan menjadi 2 yaitu, Pertama, penggabungan secara simpulan umum sebagai hukum Islam. Kedua, penggabungan secara khusus sebagai hukum Islam. (Jaih Mubarok, 2003: 116-117) Banyak Sistem hukum 
yang dibentuk tanpa adanya asas-asas hukum yang akhirnya menjadi undangundang tanpa maksud yang jelas. (Satjipto Raharjo, 2003: 140) Asas hukum Islam bersumber dari al Qur'an dan al Hadits yang selanjutnya di kembangkan dengan berijtihad. (Ahmad Hanafi, 1990: 33-35). Penafsiran terhadap asas-asas hukum ini harus dilakukan secara holistik dengan mengedepankan aspek kemaslahatan. Asas hukum Islam telah dibuat oleh Allah swt. Asas hukum Islam yang sudah sering digunakan di ilmu hukum (umum) dan melengkapi atau berlaku di Indonesia diantaranya ada asas keadilan; asas kepastian hukum; asas legalitas; asas pertanggung jawaban (pidana) dipikul sendiri dan tidak bisa diwakilkan atau dipindahkan; asas praduga tidak bersalah; asas (kepentingan yang terbaik bagi para pihak); asas mendahulukan kewajiban dan mengakhirkan hak; asas perlindungan bagi yang beriktikad baik; serta asas pembuktian secara tertulis dan kesaksian (perdata).

Masyarakat yang beragama Islam mempunyai kesempatan melakukan transformasi hukum Islam menjadi hukum nasional secara perundang- undangan dan dibantu oleh lembaga legislatif dan lebaga yudikatif. Yang menjadi masalah sekarang adalah bagaimana ahli-ahli hukum Islam dan para ulama dalam membuat hukum Islam terdahulu dengan hukum Islam baru yang sesuai perkembangan zaman yang ada dalam masyarakat tanpa mengurangi nilai hukum Islam meskipun tanpa adanya kata Islam. Dalam proses transformasi hukum Islam menjadi hukum nasional diperlukan tiga tindakan, pertama, memahami dan mengambil nilai-nilai dari Alquran dan sunnah. Kedua, dasardasar hukum dan memasukannya dalam hukm nasional Indonesia. Ketiga, pelaksanaan di dalam hukum nasional.

Masyarakat memiliki usaha untuk mengatur kehidupannya dengan dasar nilai-nilai yang mereka yakini. Masyarakat yang memeluk agama islam menganut ajaran-ajaran yang dibawa Nabi agung Muhamammad SAW. Perilaku Nabi serta ummatnya dikenal sesuai dengan syariah Islam. Masyarakat ini dalam menjalankan kehidupan juga menggunakan nilai dasar negara sebagai warga negara Indonesia. Oleh karena itu ada hubungan antara nilai dasar negara dengan nilai-nilai syariat islam, karena syariat Islam pedoman dan diterapkan 
oleh kebanyakan bangsa Indonesia. Walaupun syariat Islam ini menjadi keyakinan kebanyakan bangsa Indonesia namun tetap menghargai keyakinan warga minoritas di Indonesia, hal ini dicontohkan oleh Rasulullah dengan piagam Madinahnya.

Indonesia membentuk suatu hukum berdasarkan pada dasar negara dan Undang-Undang Dasar Negara Republik Indonesia Tahun 1945. Selain itu, juga perlu mempositifkan perbedaan hukum yang terdiri atas hukum barat, hukum adat dan hukum Islam. Dengan adanya hal ini, hukum Islam di Indonesia menjadi hukum yang dapat dilaksanakan di masyarakat selain itu juga menjadi salah satu komponen untuk membentuk hukum nasional. Hukum nasional ini yang akan membantu menyelesaikan permasalahan-permasalahan di masyarakat. Asas dan kaidah hukum Islam menjadi dasar untuk meunifikasikan hukum Islam ke dalam hukum yang ada di Indonesia.

Secara sosiologis, terdapat empat komponen hukum modern di Indonesia yaitu:

a. Hukum negara atau hukum nasional yang berada di wilayah fungsi legislatif dan eksekutif (Qanun).

b. Hukum yang berada di Lembaga peradilan yaitu hukum hakim (qada).

c. Hukum yang berada di dunia ilmiah dan perguruan tinggi yaitu hukum para ahli hukum (fikih dan fatwa).

d. Hukum berlaku dalam praktik kehidupan masyarakat ('urf).

Di Indonesia, empat macam komponen hukum modern berjalanya berbedabeda dengan sistematika yang dimiliki setiap komponen. Keadaan seperti ini akan menghambat pengembangan hukum Islam khususnya dalam bidang pembinaan hukum nasional. Oleh karena itu, menjadi instropeksi bagi negara Indonesia supaya empat macam komponen hukum modern dapat menjalankan tugas dengan bekerjasama serta saling melengkapi.

Pada dasarnya sejak zaman kolonial Belanda hingga masa kemerdekaan hingga masa kini hukum Islam berkaitan dengan hukum-hukum lainya sehingga memiliki satu kesatuan hukum yang mana menjadi hukum nasional yang berlaku di Indonesia. Hukum Islam di Indonesia dijadikan pengendali politik 
hukum pemerintah Indonesia. Dengan adanya hukum Islam di Indonesia berpengaruh pada penduduk Islam di Indonesia. Mengingat bahwa negara Indonesia merupakan negara hukum dan semua penduduk Indonesia diatur oleh hukum nasional yang tertuang pada perundang-undangan, sehingga segala cara dilakukan penduduk Islam agar aspek dalam hukum Islam dapat diterima dalam perundang- undangan di Indonesia. Dengan demikian, pemerintah dan rakyatnya diatur dan berpedoman pada hukum. Hukum tersebut didasarkan pada Pancasila dan UUD 1945. Ada beberapa teori hukum Islam yang diterapkan di Indonesia,diantaranya: pertama, teori receptie in complex. Teori yang menjelaskan bahwa hukum yang digunakan pada masyarakat asli merupakan hukum agamanya (hukum yang berlaku untuk setiap masyarakat adalah hukum agamanya masing-masing). Selain itu juga pada teori ini hukum Islam berlaku sepenuhnya pada masyarakat beragama Islam sebagai dasar untk menjalani kehidupan sehari-hari. Kedua, teori receptie . menjelaskan bahwa hukum Islam tidak secara langsung berlaku untuk orang yang beragama Islam namun hukum Islam berlaku pada masyarakat apabila dikehendaki dan diterima oleh hukum adat. Sehingga pada intinya teori ini yang digunakan sebagai pathokan pada masyarakat pribumi merupakan hukum adat. Ketiga, teori receptie exit menyatakan bahwa teori receptie atau hukum adat harus keluar dari teori hukum nasional di Indonesia karena tidak sesuai dengan UUD 1945 serta Alquran dan Sunnah. Keempat, Teori receptie a contario. Teori ini bertolak belakang dengan teori receptie. Teori ini menyebutkan bahwa hukum adat berlaku untuk masyarakat sebagai hukum agama yang dipercayainya selama tidak menentang hukum agama yang dipercayainya. Kelima, teori Eksistensi. Teori ini menjelaskan bahwa adanya hubungan antara hukum Islam dan hukum nasional. Sehingga dalam tatanan hukum nasional terdapat hukum Islam. Adanya teori diatas membuktikan bahwa hukum Islam dapat berinteraksi dengan masyarakat Indonesia maupun dengan hukum nasional. (Darussalam Syamsuddin, 2015: 3$8)$.

Dalam proses transformasi, hukum Islam mengalami proses transformasi di Indonesia dalam bidang perdata, Pemerintah Indonesia telah menyetujui dan 
mengesahkan beberapa hasil transformasi hukum Islam yang masuk kedalam perundang-undangan. Hasil transformasi ini meliputi: UU Nomor 41 Tahun 2004 yang membahas tentang wakaf, UU Nomor 38 Tahun 1999 yang membahas tentang Pengelolaan Zakat, dan UU yang mengatur tentang penyelenggaraan haji, selain itu juga ada undang-undang yang berkaitan dengan hukum bisnis dan hukum bisnis ini meliputi perbankan dan asuransi. Undangundang yang mengatur tentang perbankan syari'ah tercantum pada UU Nomor 21 tahun 2008 dan undang-undang yang mengatur tentang asuransi tercantum pada perundang-undangan Nomor 19 Tahun 2008. Selain itu hukum islam yang masuk kedalam perundang-undangan di Indonesia juga dalam bidang peradilan yang tercantum pada UU Nomor 3 Tahun 2006 yang merupakan hasil amandemen UU Nomor 7 tahun 1989. Dengan adanya amandemen ini terdapat penambahan peradilan agama yang membantu menyelesaikan permasalahan di bidang perekonomian syariah. Selain itu juga di daerah istimewa Aceh juga ada Mahkamah Syari'ah berdasarkan Undang-undang otonomi khusus tentang Kekuasaan Kehakiman yang tercantum pada pasal 1 UU Nomor 4 Tahun 2004.

Selain transformasi dalam bidang perdata juga terdapat transformasi dalam bidang pidana. Dalam bidang pidana hukum Islam dibedakan kedalam hudud, qisas, dan ta'zir. Kaidah pidana dalam hukum islam secara umum sudah terdapat dalam Al-qur'an dan Hadist dan diperluas pembahasanya dalam fikih. Di Indonesia pidana hukum Islam ditransformasikan kedalam hukum positif. Karena masih banyak pidana hukum Islam yang membutuhkan penelaahan secara mendalam dalam melaksanakannya misalnya pembunuhan. Pembunuhan ini bermacam-macam ada pembunuhan berencana, prmbunuhan salah sasaran, pembunuhan karena lalai, dan pembunuhan dalam bentuk serangan. permasalahan ini menunjukkan bahwa ayat-ayat hukum tidak bisa langsung dilaksanakan namun membutuhkan pengkajian secara mendalam untuk menjalankan hukumanya selain itu ada permasalahan-permasalahan lain seperti pengedar narkoba, pelaku terorisme dalam hukum Islam harus di pidana rajam. Namun pidana rajam ini tidak bisa dierima oleh masyarakat. Permasalahanpermasalahan dan perdebatan-perdebatan pidana menyebabkan sebuah 
kemajuan di Indonesia dalam membentuk hukum pidana. Menteri kehakiman di Indonesia membentuk tim untuk merumuskan perubahan kitab Undang-Undang Hukum Pidana (KUHP). Misalnya pada permasalahan pembunuhan dan penganiayaan dalam keluarga. Dalam hukum Islam apabila keluarga memaafkan maka sanksi pidana bisa gugur namun berbeda dengan hukum pidana di Indonesia (KUHP) pemaafan dari keluarga tidak dapat menggugurkan tidak menghentikan proses hukum. (Muwahid, 2012: 212-213) Perubahan sanksi pidana di Indonesia ini bertujuan untuk menciptakan hukum positif yang sesuai dengan keadaan masyarakat dan juga bisa berlaku adil dalam masyarakat.

Dengan adanya teori-teori sebelumnya dan juga penjelasan mengenai transformasi hukum Islam di Indonesia menunjukkan bahwa hukum Islam ini saling berkaitan dengan hukum-hukum lainya. Di Indonesia juga memiliki hukum positif yang disebut dengan Kompilasi Hukum Islam. Kata kompilasi berasal dari kata dalam bahasa inggris compilation dan beasal dari bahasa Belanda compilatie yang artinya menjadikan satu peraturan-peraturan. Kata kompilasi digunakan di Indonesia. Dilihat dari arti the ideal law, Kompilasi Hukum Islam ialah kumpulan hukum di Indonesia yang mengandung aturan untuk mengatur kehidupan masyarakat islam Indonesia (Yulkamain Harahab dan Andy Omara, 2010: 629).

Kompilasi Hukum Islam di Indonesia dimulai dimulai sejak adanya Instruksi Presiden Nomor 1 Tahun 1991 tanggal 10 Juni 1991. Jika dilihat dari lahirnya kompilasi hukum Islam ini tidak termasuk kedalam peraturan perundang-undangan karena bersifat instruksi atau perintah tetapi jika ditinjau dari isinya dan hal-hal yang terkandung di dalamnya kompilasi hukum Islam ini termasuk peraturan perundang- undangan dan dan dikuatkan oleh Keputusan Mentri Agama Nomor 154 tahun 1991 tanggal 22 Juli 1991. Ada 3 hal inti dari Inpres Nomor 1 tahun 1991 dan Keputusan Menteri Agama Nomor 154 tahun 1991 meliputi: pertama, menyebarkan KHI supaya menjadi hukum yang bisa diterapkan dalam kehidupan masyarakat. Kedua, rumusan dalam KHI bertujuan untuk menghilangkan anggapan hukum islam yang ganda. Ketiga, menjelaskan 
bahwa KHI berlaku pada pemerintah dan rakyat yang memerlukanya. (Yulkamain Harahab dan Andy Omara, 2010: 630).

Kompilasi Hukum Islam menjadi pedoman para hakim dan masyarakat Indonesia. (Mahsun Fuad, 2005: 3). Karena secara umum kompilasi sudah dianggap sebagai hukum positif di Indonesia. Dalam setiap menyelesaikan masalah para hakim melibatkan kompilasi hukum Islam dan bahkan para hakim tidak pernah melupakan aturan-aturan dalam kompilasi hukum islam karena kompilasi hukum islam dianggap fiqh yang menjadi hukum fiqh khas Indonesia. Pada awalnya Hukum Islam merupakan hukum yang ada di kitab-kitab fiqih yang banyak perdebatan. Sehingga, indonesia berusaha meunifikasikan hukum Islam dalam bentuk kompilasi. Jadi, hukum Islam di Indonesia telah diunifakisan dalam KHI Indonesia yang disesuaikan dengan keadaan lingkungan masyarakat pada masa sekarang. Perubahan hukum Islam menjadi kompilasi tetap memperhatikan dasar-dasar hukum Islam.

Tujuan utama KHI yaitu supaya hukum Islam menjadi positif di Indonesia dengan memperhatikan sistematika hukum Islam yang terdapat dalam kitab. Sehingga untuk mecapai tujuan KHI terdapat pokok-pokok yang menjadi tujuan KHI (Cik Hasan Bisri, 1999 : 27-35) antara lain: pertama, melengkapi komponen hukum dalam Peradilan Agama.melengkapi komponen hukum dan peradilan agama ini maksudnya melengkapi komponen hukum Islam yang belum ada pada peraturan perundang-undangan di Indonesia. kedua, menyelaraskan anggapan mengenai perwujudan hukum. Maksudnya dengan adanya kompilasi hukum Islam, perdebatan-perdebatan yang ada dalam fiqh islam dijadikan satu pemikiran. Ketiga, Mempercepat proses hukum keluarga. Keempat, menghilangkan paham Private Affairs. Maksud dari Private Affairs yaitu menghilangkan paham mementingkan urusan pribadi. Dengan adanya kompilasi hukum Islam ini masyarakat harus mematuhi hukum-hukum yang sudah ada di Indonesia. Karena aturan-aturan dalam kompilasi hukum Islam ini sudah diambil jalan tengah yang tujuanya agar menghindari perdebatan di masyarakat karena setiap individu memiliki paham yang berbeda. (Mahsun Fuad, 2005: 631). 
Hal- hal yang dibahas dalam Kompilasi Hukum Islam meliputi: Pertama, hukum yang mencakup perkawinan, terdiri dari: penjabaran UU Nomor 1 Tahun 1974, berkaitan dengan adanya banyak hukum keluarga, antara lain menjelaskan dasar-dasar materi perkawinan, tata aturan pembatalan perkawinan, penentuan hak asuh anak dalam perceraian, perluasan perwalian, dasar-dasar tentang perceraian. Kedua, Hukum Perwarisan terdiri dari: materi pembagian harta secara umum, wasiat untuk anak angkat, pembagian harta untuk anak laki-laki dan perempuan. Ketiga, Hukum Perwakafan terdiri dari: materi umum perwakafan, tanggung jawab perwakafan yang jelas, pembahasan benda dan tanah wakaf. (Muji Mulia, 2005: 78).

Dengan adanya kompilasi hukum islam (KHI) di Indonesia, masyarakat Indonesia memiliki pedoman untuk menjalankan kehidupan sehari-hari. Permasalahan di tengah-tengah masyarakat bisa teratasi dengan aturan yang sesuai dengan hukum keagamaan maupun hukum nasional. Selain itu perdebatan-perdebatan pun dapat teratasi dengan adanya kompilasi hukum Islam.

\section{Penutup}

\section{A. Kesimpulan}

Hukum Islam ada di Indonesia karena adanya proses transformasi. Proses ini bertujuan untuk memasukkan hukum Islam kedalam Hukum di Indonesia. Dengan masuknya hukum Islam di Indonesia bertujuan untuk mengatur masyarakat islam yang ada di Indonesia dengan catatan peraturan itu tidak menentang dasar negara dan UUD Negara Republik Indonesia 1945. Hukum Islam ini juga di unifikasikan dengan hukum nasional di Indonesia. Unifikasi hukum Islam dengan hukum nasional di Indonesia disebut dengan Kompilasi Hukum Islam (KHI). Kompilasi Hukum Islam di Indonesia dijadikan hukum positif karena sesuai dengan dasar negara Indonesia. Dengan adanya transformasi hukum Islam di Indonesia masyarakat memiliki hukum positif yang sesuai dengan keyakinan dan aturan-aturan yang berlaku di Indonesia. Selain itu dengan adanya kompilasi hukum islam yang juga hasil dari proses transformasi 
hukum islam diharapkan bisa menyelesaikan permasalahan yang ada di dalam kehidupan masyarakat. Bahkan dengan adanya kompilasi hukum islam ini bisa mengurangi perdebatan hanya karena memiliki perbedaan pendapat.

\section{B. Saran}

Kompilasi Hukum Islam merupakan bukti adanya transformasi hukum islam di Indonesia, untuk itu saran yang diajukan adalah:

1. Kita harus memahami adanya transformasi hukum Islam di Indonesia agar hukum di Indonesia dapat berjalan dalam masyarakat dengan baik.

2. Kita harus memahami Kompilasi Hukum Islam (KHI) untuk dijadikan dasar dan sumber hukum dalam menyelesaikan permasalahan bagi masyarakat, dst.

\section{Daftar Pustaka}

Biga, Nurhikmah Hairak, "History of Renewal of Islamic Family Law in Indonesia”. Al-Mizan: Jurnal Pemikiran Hukum Islam. Vol. 13, No. 2, 2017.

Bisri, Cik Hasan, Kompilasi Hukum Islam dan Peradilan Agama dalam sistem Hukum Nasional. Jakarta: Logos Wacana Ilmu, 1999.

Departemen Pendidikan Nasional. Kamus Besar Bahasa Indonesia. Jakarta: Balai Pustaka, 2005.

Fuad, Mahsun Fuad. Dari Nalar Partisipatoris Hingga Emansipatoris. Yogyakarta: LKIS Yogyakarta, 2005.

Hanafi, Ahmad, Asas-Asas Hukum Pidana Islam. Jakarta: Bulan Bintang, 1990.

Harahab, Yulkarnain dan Andy Omara, "Kompilasi Hukum Islam dalam Perpektif Hukum Perundang-undangan”. Mimbar Hukum. Vol. 22, No. 3, Oktober 2010.

Herawati, Andi, "The Existence of Islamic Law Compilation Article 183 in Solving Inheritance Issue of Muslim Communities in Makassar". Aldaulah: Jurnal Hukum Pidana \& Ketatanegaraan. Vol. 8, No 1, 2019. 
Imron, Ali, “Transformasi Hukum Islam ke Dalam Hukum Nasional Indonesia”. Jurnal Hukum dan Dinamika Masyarakat. Vol. 5, No. 2, April 2008.

Muwahid, "Transformasi Hukum Islam dalam Sistem Hukum Nasional”. AlManahij: Jurnal Kajian Hukum Islam. Vol. 6, No. 2, Juli 2012.

Mubarok, Jaih, "Dinamika Pemikiran Hukum Islam di Indonesia". Jurnal Unisia UII Yogyakarta. Vol. 26, No. 48, 2003.

Mulia, Muji, "Pembaharuan Hukum Islam di Indonesia (Analisis Historis tentang Kompilasi Hukum Islam)". Jurnal Islam Futura. Vol. 7, No.1, 2008.

Rahardjo, Satjipto. Sisi- Sisi Lain Dari Hukum di Indonesia. Jakarta: Penerbit Buku Kompas, 2003.

Sadat, Anwar, "Strategi Transformasi Hukum Islam dalam Pembinaan Hukum Nasional". Jurnal Syari'ah dan Hukum Diktum. Vol. 16, No. 1, Juli 2018.

Syamsuddin, Darussalam, "Transformasi Hukum Islam di Indonesia", Jurnal AlQadāu. Vol. 2, No. 1, 2015.

Wahid, Marzuki dan Rumadi. Fiqh Madzhab Negara: kritik atas politik hukum Islam di Indonesia. Yogyakarta: LKIS Yogyakarta, 2001.

Yasa, Ahmad, "The Development of Indonesian Islamic Law: A Historical Overview”. Journal of Indonesian Islam. Vol. 9, No 1, Juni 2015. 